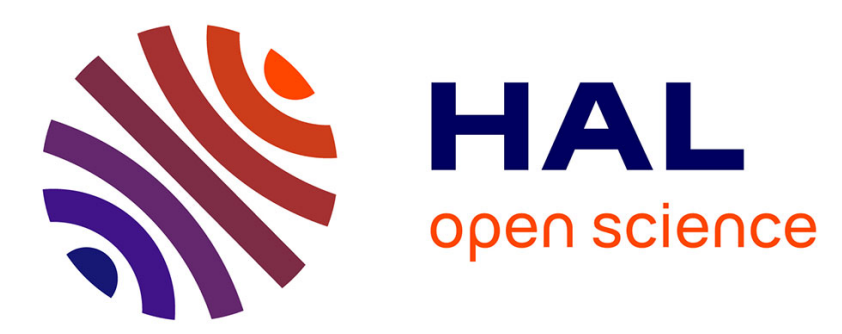

\title{
An assessment of government funding of business angel networks in Flanders
}

\author{
Veroniek Collewaert, Sophie Manigart, Rudy Aernoudt
}

\section{To cite this version:}

Veroniek Collewaert, Sophie Manigart, Rudy Aernoudt. An assessment of government funding of business angel networks in Flanders. Regional Studies, 2010, 44 (01), pp.119-130. $10.1080 / 00343400802070860$. hal-00565123

\section{HAL Id: hal-00565123 \\ https://hal.science/hal-00565123}

Submitted on 11 Feb 2011

HAL is a multi-disciplinary open access archive for the deposit and dissemination of scientific research documents, whether they are published or not. The documents may come from teaching and research institutions in France or abroad, or from public or private research centers.
L'archive ouverte pluridisciplinaire HAL, est destinée au dépôt et à la diffusion de documents scientifiques de niveau recherche, publiés ou non, émanant des établissements d'enseignement et de recherche français ou étrangers, des laboratoires publics ou privés. 


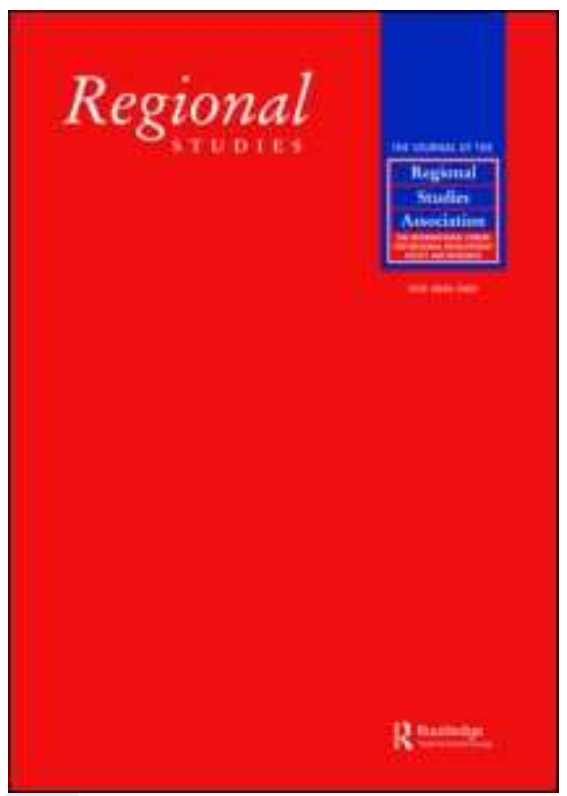

\section{An assessment of government funding of business angel networks in Flanders}

\begin{tabular}{|c|l|}
\hline Journal: & Regional Studies \\
\hline Manuscript ID: & CRES-2006-0164.R3 \\
\hline Manuscript Type: & Policy Debates \\
\hline JEL codes: & $\begin{array}{l}\text { G24 - Investment Banking|Venture Capital|Brokerage < G2 - } \\
\text { Financial Institutions and Services < G - Financial Economics, H71 - } \\
\text { State and Local Taxation, Subsidies, and Revenue < H7 - State and } \\
\text { Economics, M13 - Entrepreneurship < M1 - Business Administration } \\
<\text { M - Business Administration and Business Econ; Marketing; } \\
\text { Accounting, R58 - Regional Development Policy < R5 - Regional } \\
\text { Government Analysis < R - Urban, Rural, and Regional Economics }\end{array}$ \\
\hline Keywords: & $\begin{array}{l}\text { risk capital, business angels, policy, economic development, market } \\
\text { failure }\end{array}$ \\
\hline \hline
\end{tabular}

\section{SCHOLARONE Manuscripts}




\title{
AN ASSESSMENT OF GOVERNMENT FUNDING OF BUSINESS ANGEL NETWORKS
}

IN FLANDERS

\author{
VERONIEK COLLEWAERT \\ Department of Accounting and Corporate Finance (Ghent University), Kuiperskaai 55E, 9000 \\ Gent, Belgium \\ e-mail: veroniek.collewaert@ugent.be

\section{SOPHIE MANIGART} \\ Department of Accounting and Corporate Finance (Ghent University), Kuiperskaai 55E, 9000 \\ Gent, Belgium \\ Competence Centre Accounting and Finance (Vlerick Leuven Gent Management School), \\ Reep 1, 9000 Gent, Belgium \\ e-mail: sophie.manigart@ vlerick.be
}

\author{
RUDY AERNOUDT \\ EHSAL, University College Ghent and Nancy University \\ Lindenpark 48, 9831 Sint-Martens-Latem, Belgium \\ e-mail: rudyaernoudt@skynet.be
}

First received: July 2006

Accepted: December 2007 


\begin{abstract}
We evaluate whether government intervention through the subsidization of business angel networks enhances regional economic growth. We show that, firstly, BANs reduce the information and financing problems entrepreneurial companies face. Secondly, these companies contribute to economic development and growth. Thirdly, there are positive indicators of future potential, such as an upward evolution in value creation and ability to raise follow-on financing. Finally, the programme has many positive indirect effects. This leads us to tentatively conclude that public BAN support is warranted. However, to make this conclusion more robust requires a longer-term evaluation.
\end{abstract}

JEL Codes: G24, H71, M13, R58

Keywords: risk capital, business angels, policy, economic development, market failure

Une évaluation des finances publiques en faveur des réseaux de bailleurs de fonds en Flandres.

Collewaert et al.

On cherche à évaluer si, oui ou non, l'intervention du gouvernement par moyen des subventions en faveur des réseaux de bailleurs de fonds augmente la croissance économique régionale. On montre que, primo, les réseaux de bailleurs de fonds (BANs; Business Angel Networks) atténuent les problèmes que doivent affronter les entreprises entrepreneuriales dans les domaines de l'information et des finances. Secundo, ces entreprises contribuent au développement et à la croisssance économiques. Tertio, il y a des clignotants positifs quant au potentiel futur, tels un mouvement vers le haut de la création de valeur et la capacité à trouver des finances complémentaires. Pour finir, le programme a beaucoup d'effets indirects positifs. Cela amène à conclure provisoirement que les finances publiques en faveur des BANs sont justifiées. Cependant, il faut une évaluation à plus long terme pour affirmer cette conclusion.

Capital-risque / Bailleurs de fonds / Politique / Développement économique / Distorsion du marché 
Classement JEL: G24; H71; M13; R58

\title{
Eine Bewertung der staatlichen Finanzierung von Business-Angel- Netzwerken in Flandern
}

VERONIEK COLLEWAERT, SOPHIE MANIGART and RUDY AERNOUDT

\begin{abstract}
Wir untersuchen, ob sich durch eine staatliche Intervention in Form einer Subventionierung von Business-Angel-Netzwerken das regionale Wirtschaftswachstum verbessert. Gezeigt wird erstens, dass Business-AngelNetzwerke die Informations- und Finanzierungsprobleme junger Firmen reduzieren. Zweitens tragen diese Firmen zur Wirtschaftsentwicklung und zum Wirtschaftswachstum bei. Drittens liegen positive Indikatoren für das Zukunftspotenzial vor, wie z. B. hinsichtlich einer Aufwärtsevolution bei der Wertschaffung und der Fähigkeit zur Sicherung von Nachfolgefinanzierung. Schließlich hat das Programm zahlreiche positive indirekte Auswirkungen. Diese Ergebnisse veranlassen uns zur vorsichtigen Schlussfolgerung, dass eine öffentliche Unterstützung von Business-Angel-Netzwerken empfehlenswert ist. Allerdings ist eine längerfristige Bewertung erforderlich, um dieses Fazit robuster zu gestalten.
\end{abstract}

JEL Codes: G24, H71, M13, R58

Keywords:

Risikokapital

Business Angels

Politik

Wirtschaftsentwicklung

Scheitern auf dem Markt

Valoración de la financiación estatal de las redes de inversión privada en Flandes

Veroniek Collewaert, Sophie Manigart And Rudy Aernoudt

ABSTRACT

Aquí evaluamos si mediante una intervención estatal en forma de subsidio de las business angel networks (BAN) o redes de inversión privada es posible aumentar el crecimiento económico regional. En primer lugar, mostramos que las BAN reducen los problemas de información y financiamiento de las sociedades empresariales. En segundo lugar, estas sociedades contribuyen al desarrollo y crecimiento económicos. En tercer lugar, existen indicadores positivos del potencial futuro, por ejemplo una evolución ascendente en la creación de valores y la habilidad para procurar una financiación de seguimiento. Por último, el programa tiene muchos efectos positivos indirectos. Esto nos lleva a concluir provisionalmente que es recomendable un apoyo público de las BAN. Sin embargo, para que esta conclusión sea más sólida es necesaria una evaluación a largo plazo. 
Keywords:

Capital de riesgo

Ángeles Inversores

Política

Desarrollo económico

Fallo mercantil

JEL Codes: G24, H71, M13, R58 


\section{INTRODUCTION}

Over the past decade, governments from all over the world have launched initiatives to stimulate risk capital markets (EUROPEAN COMMISSION, 2003b; MAULA et al., 2007). Risk capital refers to external equity financing of entrepreneurial companies and encompasses both formal venture capital (VC) and informal risk capital, also known as business angel (BA) financing (EUROPEAN COMMISSION, 2001). Formal VC is provided by institutional, professional investors, while BA financing is provided by private investors with no family or friend connections to their investees (HARRISON and MASON, 1999; EVCA, 2002). Sohl (2005) estimates that 227,000 U.S. BAs invested $\$ 23.1$ billion in 49,500 companies in 2005 , compared to VC investors investing $\$ 21.7$ billion in only 2,939 companies (PRICEWATERHOUSECOOPERS et al., 2006). There is a relative scarcity of statistics on European BA investments. Mason (2006) estimates that 20,000 to 40,000 U.K. angels yearly invest $£ 0.5$ billion to $£ 1$ billion in 3,000 to 6,000 companies, backing eight times more startups than VC investors.

While a small number of growth-oriented start-ups contribute disproportionately to innovation, economic growth and job creation (e.g. WONG et al., 2005; FRITSCH and FALCK, 2007), policy makers believe that there is a market failure in that many entrepreneurial companies are prevented from exploiting growth opportunities due to a lack of risk capital (MASON and HARRISON, 2003; CARLSON and CHAKRABARTI, 2007). Hence they have established support programmes to stimulate risk capital financing and thereby foster economic growth (CUMMING, 2007). This perceived failure in risk capital markets is addressed either by directly increasing the supply of risk capital or by increasing 
expected returns to investors through decreasing taxation, improving exit markets, or reducing barriers to entrepreneurship (DA RIN et al., 2006).

Risk capital has been shown to have a strong regional dimension, with risk capital investors often specializing in investing in a geographically concentrated region (CARLSON and CHAKRABARTI, 2007; CHRISTEN, 2007). Whereas the European Commission argues that VC activity needs to be regionally clustered in order to create necessary levels of specialization within high-tech clusters, the OECD and some EU member states have argued for a more even regional distribution (MARTIN et al., 2002). Following the latter view, government policies throughout Europe and the U.S. have often focused on ensuring an adequate regional supply of risk capital (e.g. VENKATARAMAN, 2004; CHRISTEN, 2007).

Various studies have assessed the impact of public policies aimed at stimulating formal VC markets (e.g. LERNER, 1999; 2002; AYAYI, 2004; DA RIN et al., 2006; CUMMING, 2007). There is, however, a lack of insight into the effectiveness and efficiency of policies targeted towards BAs, such as tax reliefs, support of BA networks (BANs) or BA coinvestment funds (MAULA et al., 2007). In the current paper, we evaluate one type of government intervention programme to stimulate informal risk capital: the support of BANs. We focus on one Belgian region, Flanders, as this allows an in-depth assessment. We assess whether the programme is warranted by evaluating whether it is based on the right assumptions and has achieved its goals.

We proceed by providing theoretical rationales for government intervention in the informal risk capital market and describe how and why the Flemish government has supported BANs. 
Thereafter, we discuss the research method used to evaluate the programme. In the results section, we evaluate its direct effects and briefly discuss its indirect effects.

\section{GOVERNMENT INTERVENTION IN THE INFORMAL RISK CAPITAL MARKET}

Government intervention in the informal risk capital market is based on a market failure argument, caused by R\&D externalities and information problems (EUROPEAN COMMISSION, 2003b; MURRAY, 2007). R\&D externalities refer to the fact that the value of R\&D investments is not fully internalized, as they generate benefits for parties outside the company (LERNER, 1999). While investors would like to appropriate all returns generated by high-potential companies given their high perceived risks (DA RIN et al., 2006; MURRAY, 2007), R\&D externalities prevent this, leading investors to provide less financing than would be socially optimal (CUMMING, 2007; MURRAY, 2007). Small firms might be especially prone to this due to "their lesser market power and inability to finance the aggressive defence of intellectual ownership infringements" (MURRAY, 2007, p. 14).

A second source of market failure is the high level of information asymmetry in small and young companies, caused by a lack of track record and profit generation and resulting in high uncertainty for investors. Hence, these companies are constrained from access to public capital markets and bank financing (DA RIN et al., 2006). Moreover, R\&D investments do not create collateralisable assets. As financing of low-collateral companies requires monitoring (HOLMSTROM and TIROLE, 1997), arm's-length lenders constrain credit towards these companies (DA RIN et al., 2006). Therefore, they have to rely on BAs or VCs as they more actively monitor their investments (BERGER and UDELL, 1998). 
VCs and BAs mitigate information problems, which may result in adverse selection and moral hazard risks, through extensive due diligence pre-investment, writing extensive contracts at investment and monitoring post-investment (BERGER and UDELL, 1998). However, due to scale economies in these costly processes and in order to further reduce risk, VCs have shifted their focus toward larger and older investments (EUROPEAN COMMISSION, 2003a; MASON and HARRISON, 2003). Furthermore, VC investments tend to be geographically concentrated and focused on a few industries (LERNER, 2002; CARLSON and CHAKRABARTI, 2007; CHRISTEN, 2007). Hence, it is argued that small and young ventures, especially those active in regions or industries with little VC, have difficulties in raising sufficient capital even if they have great value-creating potential. Therefore they resort to BA funding, which therefore may be particularly important in regions where VC is lacking (MASON and HARRISON, 1995).

Another information problem is the lack of transparency in the informal risk capital market. Entrepreneurs are not always fully informed about the array of possible financing sources and their characteristics (VAN AUKEN, 2001). Even if they understand BA financing, they are not always able to locate BAs, as these often do not want to make their investment intentions public. In the same vein, BAs have trouble in locating valuable investment opportunities (MASON and HARRISON, 2002). These problems led to the creation of BANs, which provide an information channel between entrepreneurs and BAs without giving up the privacy of the latter (HARRISON and MASON, 1996b).

Conclusive evidence concerning the existence of a market failure is lacking (MAULA and MURRAY, 2003; JÄÄSKELÄINEN et al., 2006), as the lack of risk capital may be due more to the poor quality of the demand than to the unavailability of capital (MASON and 
HARRISON, 2002; 2003). Venkataraman (2004) argues that risk capital is a necessary, but non-sufficient condition for fostering regional growth-oriented entrepreneurship. Intangible regional assets, such as access to novel ideas, role models or region-specific opportunities, are equally important. Merely injecting risk capital in a region may thus lead to promoting lowquality entrepreneurship (VENKATARAMAN, 2004).The lack of financing per se is not enough to constitute a market failure; the financing constraint has to regard value-creating companies.

\section{REGIONAL APPROACH TO INFORMAL RISK CAPITAL: BUSINESS ANGEL}

\section{NETWORKS}

Increasingly, governments take a regional approach to reduce the perceived risk capital market failure (EUROPEAN COMMISSION, 2006): policy is implemented at the lowest level possible, on the condition that it is still efficient (SUNLEY et al., 2005). In addition to addressing specific regional market conditions, regional risk capital programmes are also warranted as geographic proximity is important in the early-stage investor-investee relationship (SUNLEY et al., 2005; CARLSON and CHAKRABARTI, 2007). For an investment to take place, face-to-face contact between investor and investee is required to reduce information asymmetries and create trust (EBAN, 1998; AERNOUDT, 1999). Proximity further facilitates active coaching and advising, allowing companies to benefit more from the investor's network and effort (MASON and HARRISON, 1995; SUNLEY et al., 2005).

One regional measure aimed at facilitating early-stage funding is the public funding and support of BANs. Based on an evaluation of the potential of establishing regional BANs in 
Europe and the positive results of a pioneer programme in the U.K., the Commission stimulated, facilitated and financed the establishment of BANs in the late nineties (EBAN, 1998; HARRISON and MASON, 1999). Other measures that stimulate the informal risk capital market, such as tax incentives, improved legislation, education of BAs and entrepreneurs or co-investment schemes, cannot work effectively without first reducing search problems (MASON, 2006).

Europe counted 231 BANs in 2005, of which $68 \%$ were publicly funded (EBAN, 2005a;b). It was initially assumed that public subsidies were needed to launch BANs, but that these could become self-supporting after five years thanks to revenues from membership fees, success fees or sponsoring (HARRISON and MASON, 1996a; VAN ROMPUY, 1999). This assumption is, however, not confirmed (HARRISON and MASON, 1996a). Governments are now confronted with the question whether subsidies have to cease as initially foreseen - which would result in most BANs closing down - or whether long-lasting structural subsidies are justified to maintain the BANs. A critical evaluation of BAN support is hence timely. The success of BANs has been both widely endorsed and strongly contended, but there is no agreement on their effectiveness (HARRISON and MASON, 1996a;b; MASON and HARRISON, 2002). Harrison and Mason (1996a;b) provided the only BAN evaluation study to our knowledge and so represents our only benchmark. In order to advance their work and make a thorough evaluation of the cost-effectiveness of public BAN support, we concentrate on one region in Belgium, Flanders, from 1999 to 2004.

The first Belgian BAN, Vlerick BAN, was subsidised by the Flemish government in 1999. Three other BANs were subsequently founded and subsidized. Together, they were the only BANs operating in Flanders until 2004 (after which they all merged) and all operated in the 
same way, through investor forums. These forums are events where entrepreneurs can pitch their ideas face-to-face to BAN members and discuss them in more depth with potentially interested BAs (EUROPEAN COMMISSION, 2003a). The Flemish government, following the European Commission's rationales, considered the BANs as a way to reduce the financing problems entrepreneurial companies face, through reducing information problems (VAN ROMPUY, 1999). The financing of the networks was considered as one way to promote entrepreneurship and innovation in Flanders (VAN ROMPUY, 1999).

Together, these four BANs represented $140 \mathrm{BAs}^{1}$ and 58 deals in 55 companies, in which 54 BAs invested between 1999 and 2004. The total amount of subsidies granted to the four BANs between 1999 and 2004 was $€ 856,741$, representing $50 \%$ of their operating costs. The subsidy per deal was $€ 14,800$ or $21 \%$ lower than the $€ 18,900$ per deal for the British Department of Trade and Industry's (DTI) informal investment demonstration projects (HARRISON and MASON, 1996b).

Evaluating public funding of BANs within one region has advantages. The four BANs all operate within the same economic, legislative and fiscal environment, increasing the internal validity of the evaluation. The external validity of the study is nevertheless warranted based on following arguments. First, Belgian socio-economic indicators as income distribution, employment rate, social security fees and trade balance are similar to indicators in other European countries such as Germany, the Netherlands, France, Austria, Spain and Italy (STROOBANDT et al., 2005). Second, the Flemish BANs are similar to BANs in comparable European countries. A Flemish BAN closed, on average, 4.5 deals in 2003, compared to 0.2, 4.7 and 6 deals per BAN in Italy, the Netherlands and Spain, respectively. A Flemish BAN counted, on average, 35 BA members compared to 26 members in Germany, 35 in Italy and 
45 in Spain (EBAN, 2005a). The informal risk capital market is less mature in Continental Europe than in the U.S. and U.K. (EBAN, 2005a). For example, the U.K. counted 34 BANs in 2004, a number similar to the U.S., with an average of 5 deals per BAN (EBAN, 2005b). Third, the fiscal treatment of BA investments is comparable to that in other countries, except that capital gains realised by private individuals are not taxed. Finally, Flanders is a region with 5 million inhabitants and thus fits into the criteria suggested for establishing a BAN (EBAN, 1998). Hence, its evaluation can present relevant conclusions for other European regions.

\section{HOW TO EVALUATE GOVERNMENT PROGRAMMES?}

According to Lerner and colleagues, the "starting point for any evaluation of a government programme is the goals it was designed to achieve" (LERNER et al., 2005, p. 140), which is what most evaluation studies do (e.g. BOYNS et al., 2005; MAULA and MURRAY, 2003; AYAYI, 2004; LERNER et al., 2005; CUMMING, 2007). Through BAN subsidies, the Flemish government's goal was to stimulate regional entrepreneurship, innovation and job creation by reducing the perceived information and financing problems (sub-goals) entrepreneurial companies face (VAN ROMPUY, 1999). The BANs' mission was to create a market where entrepreneurs looking for finance and BAs looking for investments could find each other. In addition, one needs to assess the assumptions the initiative and its objectives are based upon (MAULA and MURRAY, 2003). The assumption the Flemish government and the European Commission made when subsidising BANs was that there was a market failure, namely that some value-creating entrepreneurial companies suffered from financing problems. Finally, in order to assess the full impact of a government programme, one needs to go beyond its direct effects (HARRISON and MASON, 1996b; LERNER, 1999). Positive 
indirect effects of the BAN subsidies may include the enhancement of overall awareness for BA financing or entrepreneurs' and investors' education.

Therefore, in order to evaluate government funding of BANs, we need to answer following questions:

1. Is there a failure in the informal risk capital market?

a. Did the companies financed through BANs suffer from information problems and resulting financing constraints?

b. Were these companies value-creating?

2. Do BANs reduce the financing problems of entrepreneurial companies?

3. Do these companies contribute to regional economic development?

4. What are the indirect effects of the BAN subsidies?

\section{RESEARCH METHOD}

Researchers have generally used either one of two approaches to study the foregoing questions. Some relied on qualitative data by gathering general information on the government measures taken and/or by interviewing beneficiaries or experts (e.g. MURRAY, 1998; DOSSANI and KENNEY, 2002; MAULA and MURRAY, 2003). Others compared the performance of beneficiaries to that of comparable non-beneficiaries using a quantitative approach (e.g. LERNER, 1999; AYAYI, 2004; CUMMING, 2007). A contribution of our study is that we combine both approaches, leading to a richer understanding and rigorous analysis of the research questions. 
We first solicited interviews from the beneficiaries, being all 55 entrepreneurs and 54 BAs who were involved in a deal through one of the four Flemish BANs. This resulted in 28 interviews with entrepreneurs (including three of which managed failed companies) and 34 interviews with BAs. The interviews give insight into how market participants, i.e. entrepreneurs and investors, perceive market failure in terms of information and financing problems and in the contribution of BANs in reducing this failure.

As interviews provide subjective views, we complement them with hard data, namely the financial accounts of all companies that received BA financing through one of the BANs (BAN-backed companies). We compare their debt capacity prior to BA investment to that of a matched benchmark group of non-BA-backed companies. In order for a market failure to exist, BAN-backed companies should have depleted their debt capacity prior to BA investment. If not, they should be able to access traditional debt financing sources. A firm has depleted its debt capacity if its financial risk, measured as the ratio of the book value of debt to total assets, is high or if it does not have the capacity to service the fixed interest and principal repayments attached to debt, measured by its internally generated cash flows (LEMMON and ZENDER, 2004). We add profitability measures such as return on assets, pre-tax profit and operational profit as further indicators of a firm's risk (e.g. ALTMAN, 1968).

A second pre-investment comparison relates to companies that did not resort to a BAN but nevertheless received BA financing. This is relevant as one might argue that, in an efficient risk capital market, entrepreneurs with value-creating projects should be able to raise BA financing even without a BAN. First, having a poor personal network might be an indication of the inability of the entrepreneur to network with third parties that are relevant for 
conducting business, hence increasing the odds that the entrepreneur will not be able to develop the venture satisfactorily. Second, parties within an entrepreneur's network face lower information asymmetries, as they are able to better assess potential agency problems. Failure to find a personally known investor might be an indication of excessive agency risk. Hence, entrepreneurs with a high ability and low agency risk should be able to find a BA without a BAN. If the above reasoning holds, we expect BAN-backed companies to be more risky than companies that found BA financing through another channel. If, however, the risk of both groups is the same, then this is additional evidence of market inefficiencies.

Further, in order for a market failure to exist, companies facing financing constraints should have value-creating projects. In order to assess how "effectively and profitably" (MURRAY, 2007, p. 8) the BAN-backed companies employ their financing, we measure their return on assets (ROA) from the year of BA participation up to four years thereafter. Ideally, we should compare ROA to the companies' funding cost to assess value creation. As it is difficult to estimate the funding cost of unquoted companies, we compare the ROA of BANbacked companies to both that of non-BA-backed companies and companies that found BA financing through another channel. Hence, we assume that these companies have a comparable funding $\operatorname{cost}^{2}$. Additionally, we conduct the same analyses on value added - a proxy for sales - (rescaled by total assets) as a robustness check. Value-added is the difference between operating income and the value of inputs.

In order to assess whether BAN-backed companies contribute to economic development, we studied the absolute amount and growth in employment and value-added (LERNER, 1999; EVCA, 2002) and the federal taxes paid by the BAN-backed companies (EVCA, 2002). Growth is calculated as the average yearly growth from the year of BA investment to the last 
available year (HEIRMAN and CLARYSSE, 2005). This growth measure has limitations as it assumes a linear growth process. Furthermore, a longer-term growth measure would be more desirable (LERNER, 1999), but unfortunately data that would enable this analysis are not available.

The population of BAN-backed companies is identified through the deal list of the four Flemish BANs. The sample of companies that received BA financing through another channel is based on two sources: (i) the interviews with the BAs who have invested through a BAN and were asked to identify all their investments, (ii) a database with the financing sources of 221 Flemish high-tech start-ups (HEIRMAN and CLARYSSE, 2005). After removing overlaps between data sources and companies that we could not further identify, we retained 44 BAN-backed companies and 66 BA-backed companies that found a BA through another channel. Further, companies that received BA financing before 1992 and after August 2003 were also removed. The final samples consist of 34 BAN-backed companies and 50 BAbacked companies that received BA financing through another channel.

In order to assess the marginal impact of a government programme, we need a sample of similar companies that did not benefit from this programme (LERNER et al., 2005). Hence, we match the BAN-backed companies to non-BA-backed companies on age, industry and size (LERNER, 1999; PURI and ZARUTSKI, 2007). Age is measured in the year prior to BA participation or the year of BA participation if the BA participated at start-up. Second, we match the BAN-backed companies on industry based on the NACE-BEL codes (comparable to 3-digit SIC codes). Third, we match on size, proxied by total assets. 
SAMPLE DESCRIPTION

The 34 interviewed $\mathrm{BAs}^{3}$, representing 36 out of the 55 BAN-backed companies, have invested $€ 11.7$ million through a BAN or $€ 324,489$ per company. Extrapolating this amount to all BAN-backed companies, we estimate that BAs invested $€ 17.8$ million through BANs, or $€ 20.83$ per Euro of government money spent. Furthermore, the 34 BAs have invested an additional $€ 22,8$ million $^{4}$ in companies found through another channel or $€ 519,055$ per company. BAs' attitudes, investment behaviour and demographic characteristics are consistent with those of BAs in other countries (e.g. MASON, 2006), further supporting the external validity of our study.

The 28 BAN-backed companies, whose entrepreneurs were interviewed, have following characteristics. The BA participated within the first two years after incorporation in 15 out of the 28 companies. Each company has, on average, received $€ 236,571$ from BAN investors. If extrapolated, this would amount to $€ 13.0$ million invested through a BAN or $€ 15.19$ per Euro of government money spent on the BANs ${ }^{5}$. The Flemish BAN investors invested $€ 2.6$ million per year, which is twice the amount invested by the U.K. BAs under the DTI initiative in the early nineties, €1.4 million per year (HARRISON and MASON, 1996b).

The companies in the quantitative sample closely match the profile of the companies represented in the qualitative sample in terms of industry and age at BA participation. Further, the BAN-backed companies' profiles fit well into the traditional view on market failure. Young and/or small high-growth oriented and/or high-tech companies are the most likely victims of a market failure, due to $R \& D$ externalities, informational opaqueness and low levels of collateral (e.g. BERGER and UDELL, 1998; DA RIN et al., 2006; CUMMING, 
2007; MURRAY, 2007). 56\% of the companies in the sample received BA financing under the age of two; $71 \%$ received it under the age of five. Furthermore, the majority of our sample (71\%) comprises small enterprises with 10 or less employees. Finally, more than half of our sample is active in technological activities, ranging from the production of natural resources to ICT and R\&D services, to high-tech manufacturing. Fourteen companies have failed since the BA investment. Taken together, the BAN-backed companies are in the target group of high-growth oriented companies with likely market failure problems (CUMMING, 2007).

\section{MARKET FAILURE: FINANCING AND INFORMATION PROBLEMS}

Insert Table 1 about here

The qualitative and quantitative analyses suggest that financing and information problems exist in the informal risk capital market. More particularly, the pre-investment debt capacity of BAN-backed companies is significantly lower compared to non-BA-backed companies (Table 1, Panel A). As much as $96 \%$ of their assets are financed with debt, compared to $82 \%$ for the non-BA-backed sample (although the difference is not statistically significant). Their lower cash flows and profit ratios suggest that their financial risk is higher and therefore the probability of raising financing from traditional sources is lower. The qualitative interviews provide further evidence for the financing constraints. When asked why they opted for BA financing, 18 entrepreneurs stated that there were no other options. Conversely, merely 5 out of 28 entrepreneurs referred to expected BA involvement and value-added as a motive for looking for BA financing. Although 17 entrepreneurs stated that they had another investor in 
prospect at the time of BA investment - either banks or family and friends - they always admitted that both options were less suitable compared to BA money. They were either reluctant to mix personal and business life or the stringent conditions that go along with bank financing were not optimal for the company. Quantitative and qualitative results hence support the existence of financing constraints for entrepreneurial companies: these companies could probably not have found (the total amount of) financing through other sources.

We further find support for information problems in the informal risk capital market. There are no differences between the financial risk of BAN-backed companies and companies that found BAs through another channel, neither pre-investment (Table 1, Panel A) nor postinvestment (not shown in the table). This indicates that the risk of companies turning to BANs for financing is not higher than that of other BA-backed companies. In other words, BANs do not systematically attract the most risky companies unable to find financing through other channels. The only difference between the BAN-backed companies and the companies that found BAs through another channel is that the former experienced information problems in locating a BA. 20 of the interviewed entrepreneurs stated they approached a BAN as this was the only known way for them to get in contact with BAs. Conversely, only 5 entrepreneurs were confident that they would have found BA financing if the BANs had not existed.

Likewise, the BAs stated that they would not have known the companies without the BANs in $82 \%$ of the deals, confirming information problems. If the BANs had not existed, the BAs would thus not have been able to invest $€ 14.2$ million. In other words, each Euro of government subsidies has generated $€ 16.63$ of BA money, which otherwise would not have been invested in these companies. As it is possible that the BAs would have invested in other companies, the $€ 14.2$ million invested through the BANs probably overestimates the marginal 
impact of the BANs. However, $74 \%$ of the BAs stated that they still had funds left for additional investments. Taken together, qualitative and quantitative results consistently support the existence of information problems, both for BAs and entrepreneurs, and the positive role of BANs in reducing these problems. Our study provides strong support for the assumption that the informal risk capital market is plagued by information problems leading to financing constraints.

\section{MARKET FAILURE: VALUE CREATION}

The next step is to investigate whether BAN-backed companies create value. If not, a failure to raise funds outside BANs is merely the outcome of efficient resource allocation. Funding should not be channelled to non-value-creating companies.

Our results do not confirm the value-creating argument in the short term. BAN-backed companies create significantly less value than similar non-BA-backed companies and even destroy value up to three years after BA investment (Table 1, Panel B): the mean ROA of BAN-backed companies is negative, while non-BA-backed companies have positive ROAs. However, the difference between the two samples becomes less significant over the years to disappear in year 4 as the ROA of BAN-backed companies improves. The robustness check confirms these results ${ }^{6}$. The results indicate a J-curve effect: BAN-backed companies do not invest in a cost-effective manner in the short term, but this could be due to large up-front investments resulting in delayed returns ${ }^{7}$. 


\section{CONTRIBUTION TO ECONOMIC DEVELOPMENT}

The ultimate goal of the Flemish government was to stimulate regional economic growth and development (VAN ROMPUY, 1999). Important indicators hereof are job creation, taxes and value adding (LERNER, 1999; EUROPEAN COMMISSION, 2001).

The BAN-backed companies together added $€ 45.2$ million in value from the year of BA participation onwards, or, €73.2 million if extrapolated to all 55 BAN-backed companies. Each Euro of government subsidies spent on the Flemish BANs generated an estimated $€ 85.39$ in value added. The value added grows on average with $€ 73.780$ per year in BAN- 
backed companies, which is significantly more than in non-BA-backed companies. BANbacked companies hence perform better than comparable non-BA-backed companies.

Insert Table 2 about here

The BAN-backed companies in the sample paid $€ 547,000$ in taxes in a five-year period starting from the year of the BA participation. Extrapolated, all BAN-backed companies paid $€ 884,852$ in taxes. We hence estimate that each Euro of government money spent on the BANs generated a direct return of $€ 1.03$ in taxes. Following their J-curve type evolution, the BAN-backed companies initially pay significantly less taxes than the non-BA-backed companies, but this difference disappears after three years when the taxes paid by BANbacked companies increase dramatically (Table 2). It is further remarkable that they pay significantly less taxes in year 3 than companies that received BA financing through another channel.

Finally, we assess job creation using several measures. Employee growth is significantly higher in BAN-backed companies than in non-BA-backed companies and comparable to that in companies that received BA financing through another channel. If extrapolated, all BANbacked companies together employ 495 people, representing 102 net jobs created (187 jobs created minus 85 jobs destroyed) from the year of BA participation until the last available year. Each BAN-backed company has created 1.84 jobs on average over the observation period (corresponding to an average yearly growth of 0.52 FTE), representing a subsidy of $€ 8,399$ per job created. As there is a high probability that BAN-backed companies would not 
have existed without the BANs due to financing constraints, the most positive view is to consider all current 495 jobs as being additional. The subsidy per job created or retained is then $€ 1,731$. This compares to an estimated subsidy per job of $€ 1,515$ under the DTI initiative in the U.K., $€ 4,000$ under the European business incubators initiative and $€ 3,100$ under the Structural Fund initiative in Belgium (HARRISON AND MASON, 1996b; EUROPEAN COMMISSION, 2002).

The Flemish government thus succeeds in stimulating economic development and growth through the subsidization of BANs. BAN-backed companies generally contribute as much as companies that found BA financing without a BAN and significantly more than non-BAbacked companies in terms of value-added and job creation, although they do initially pay less taxes.

\section{INDIRECT EFFECTS}

An exhaustive evaluation of a government initiative needs to go beyond its direct effects (HARRISON and MASON, 1996b; LERNER, 1999). In addition to matching entrepreneurs and investors, BANs may provide other benefits, such as raising the awareness and legitimacy of BA financing, coaching and educating investors and entrepreneurs (which for the latter also entails feedback from potential investors) and enabling entrepreneurs to raise further financing thanks to BA financing, both at the time of the initial investment and later (HARRISON and MASON, 1996a;b; LUMME et al., 1998). Although hard to quantify, we briefly discuss each of these impacts. 
Due to the anonymity preference of BAs and the fact that entrepreneurs often have incomplete knowledge of financing sources (VAN AUKEN, 2001; PAUL et al., 2003), raising the awareness of potential market participants is an important task of BANs. Interviewed entrepreneurs and BAs agree that BANs have conducted a considerable awareness campaign on the existence and merits of BA financing. Furthermore, both parties considered this task to be important.

Additionally, BANs can coach entrepreneurs on writing a business plan or presenting themselves to potential investors. If BAs are not the most appropriate funding source, BANs can refer entrepreneurs to other, more suitable investors. The feedback provided by the BAs themselves may also be important. Even if entrepreneurs do not find an investor, they might strengthen their opportunity based on feedback received from the BAs they talked to. Education and training is a related task. BANs often provide specialized courses to investors and entrepreneurs on issues as negotiation, taxation or valuation. Based on our interviews, we found that entrepreneurs praise the BANs for their education and coaching. Although BAs consider the BANs to perform rather well in educating entrepreneurs, they suggest more emphasis on educating BAs although they do not consider this to be a critical task.

A final indirect effect is the fact that BA funding might enable entrepreneurs to raise additional financing, both at the time of BA financing and thereafter (HARRISON and MASON, 1996b). Cumming (2007) interprets the ability of companies to raise follow-on funding even as an indirect indication of entrepreneurial success, especially if they have not come to full fruition. Ten BAN-backed companies raised on average $€ 243,518$ from BAs not connected to a BAN and $€ 233,313$ from other sources at the time of the BA investment. More particularly, four raised money from a bank, four from the government (subsidies), one from 
3Fs, one from VCs and one from other companies. In comparison, companies benefiting from the DTI initiative raised $€ 298,516$ at the time of BA funding (HARRISON and MASON, 1996b). While Flemish BAN-backed companies raised somewhat less than their UK colleagues, this confirms the satisfactory performance of the Flemish companies.

Further, $61 \%$ of the entrepreneurs state that the BA financing had a positive impact on follow-on financing. Fourteen companies were able to raise follow-on bank financing, two VC financing and four raised financing through other channels such as government subsidies. On average, they raised another $€ 365,000$ following BA financing. According to Harrison and Mason (1996b), one quarter of the companies should be able to attract at least $50 \%$ of the original amount as follow-on financing. The Flemish BAN-backed companies performed well as one quarter of the BAN-backed companies were able to raise $168 \%$ of the original amount. This yields further positive evidence of potential future value creation (CUMMING, 2007). These results suggest that the Flemish BANs, in addition to their direct effects, also generate important positive indirect effects.

\section{CONCLUSION AND DISCUSSION}

Designing a successful programme that addresses failures in the risk capital market without crowding out the private sector is not easy. International evidence shows that countries as Israel, Australia and the US have implemented successful programmes supporting the VC market (CUMMING, 2007). The goal of the present study is to evaluate whether one type of government intervention in the informal risk capital market, namely the subsidization of BANs, is warranted. We first assessed whether the subsidies have reached their goals of reducing the financing problems of value-creating entrepreneurial companies 
and, by doing so, stimulating economic development and growth. Second, we assessed whether this intervention was based on correct assumptions. Government intervention in the risk capital market is usually based on the perception of a market failure. Therefore, we evaluated whether there is a failure in the BA market, i.e. whether there are value-creating companies that face financing problems caused by information problems or R\&D spillovers. We further assessed some indirect effects.

Based on quantitative and qualitative data, we find clear evidence of BANs reducing information and financing problems of entrepreneurial companies. BANs finance particularly young companies with high financial risk in high-tech industries. These companies are most prone to information asymmetries and financial constraints. Moreover, entrepreneurs and BAs state that they would not have known each other without BANs. The programme is additive: it increases the supply of funds to entrepreneurial companies, rather than crowding out the private sector. Further, these companies do contribute to economic development and growth. In this sense, the Flemish government programme is a success as its goals are reached. At this point in time it is hard to assess whether the supported companies create value in the long term. In the short term, they seem to destroy value, but there is an upward trend in value adding and profitability in the last years of the analysis, what might point to these companies just needing more time to deploy their resources in the most effective way. The fact that most companies are able to raise significant amounts of follow-on funding is a further indication of future potential. The Flemish BAN programme produced positive indirect effects and compares well to the UK's DTI initiative, our only benchmark (HARRISON and MASON, 1996b). In conclusion, the fact that this programme has successfully reached its goals, created many positive indirect effects and that the companies supported through this programme hold value-creating potential, lead us to conclude that public BAN support is justified. However, in 
order to make this tentative conclusion more robust, a longer-term evaluation of BAN-backed companies' value creation is indispensable.

Our study has several contributions. First, we contribute to the academic evaluation literature, as there is a scarcity of government programmes' evaluations. We contribute methodologically by combining quantitative and qualitative data. Second, our study dispels the popular view that BANs attract the worst-quality deals. Companies that seek funding through BANs are not riskier, nor do they grow less or have lower returns post-investment compared to companies that seek funding from BAs through another channel. Finally, it confirms the BANs' role in reducing information and financing problems in the informal risk capital market.

Our study has a number of limitations. First, we mainly focused on the subsidies' direct effects. As the externalities of the subsidies are hard to quantify, the impact of the government subsidies might be underestimated. Second, some positive outcomes, such as total BA money invested due to the existence of a BAN, might be over-estimated. Third, one could argue that publicly funded BANs should be compared with non-publicly funded ones. As the ultimate goal of BAN subsidies is to reduce information and financing problems of entrepreneurial companies, we consider it more relevant to study the ultimate beneficiaries of the measure. Moreover, none of the Flemish BANs would have existed without the subsidies: they were instrumental in setting up and running the BANs. There were (and still are) no Belgian BANs operating without subsidies (EBAN, 2005a).

We propose some suggestions for further research. As most BAN investments are young, we were only able to assess their post-investment performance up to four years. In order to 
assess the value creation of BAN-backed companies longer-term analyses are essential. Another interesting avenue for further research is to compare companies that had financing alternatives prior to BA investment with those without. In order to further understand the impact of direct BAN subsidies, it is interesting to compare this approach with other approaches used to stimulate BA investments, e.g. tax reliefs or co-investment schemes. Given the relatively young nature of the latter programmes, we leave this as an avenue for future research.

\section{ACKNOWLEDGEMENT}

Veroniek Collewaert is Aspirant of the Fund for Scientific Research - Flanders (FWOVlaanderen) and greatly acknowledges the financial support of the Fund. The authors would also like to thank the "Research Center Entrepreneurship and Innovation of the Flemish Community" for assistance in the data collection.

\section{NOTES}

1: This might be over-estimated as we could only exclude double counting for BAs that made BAN investments.

2: There is no significant difference in BAN-backed and non-BA-backed companies' leverage up to two years after BA participation, which supports this assumption. This does not hold for the BA-backed companies that did not resort to a BAN. Comparisons with the latter thus need to be cautiously interpreted.

3: As for representativeness tests, age and assets of the different subsamples of BAN-backed companies are not significantly different from the population of 55 BAN-backed companies. 
As we have no data on the 20 BAs who did not participate in the study, we don't know whether the interviewed BAs are representative for the BAs who have invested through one of the BANs.

4: These amounts are lower limits since not all BAs were willing to provide this information.

5: This differs from the $€ 20.83$ mentioned before since there is no perfect overlap between the interviewed BAs' investments and the interviewed companies.

6: BAN-backed companies have significantly lower value-added ratios compared to non-BAbacked companies until year 2, but the difference is not significant thereafter.

7: We thank an anonymous referee for this comment.

\title{
REFERENCES
}

\begin{abstract}
AERNOUDT R. (1999) European policy towards venture capital: Myth or reality?, Venture Capital 1, 47-57.
\end{abstract}

ALTMAN E. (1968) Financial ratios, discriminant analysis, and the prediction of corporate bankruptcy, Journal of Finance 23, 589-609.

AYAYI A. (2004) Public policy and venture capital: The Canadian labor-sponsored venture capital funds, Journal of Small Business Management 42, 335-345.

BERGER A. and UDELL G. (1998) The economics of small business finance: The roles of private equity and debt markets in the financial growth cycle, Journal of Banking and Finance 22, 613-673.

BOYNS N., COX M., SPIRES R. and HUGHES A. (2005) Research into the Enterprise Investment Scheme and Venture Capital Trusts. PACEC, Cambridge/London. 
CARLSON C. and CHAKRABARTI P. (2007) Venture capital investment in secondary cities: issues and opportunities for impact. Public and Community Affairs Discussion Papers 07-3, Federal Reserve Bank of Boston.

CHRISTEN J. (2007) The development of geographical specialization of venture capital, European Planning Studies 15, 817-833.

CUMMING D. (2007) Government policy towards entrepreneurial finance: Innovation investment funds, Journal of Business Venturing 22, 193-235.

DA RIN M., NICODANO G. and SEMBENELLI A. (2006) Public policy and the creation of active venture capital markets, Journal of Public Economics 90, 1699-1723.

DOSSANI R. and KENNEY M. (2002) Creating an environment for venture capital in India, World Development 30, 227-253.

EBAN (EUROPEAN BUSINESS ANGEL NETWORK) (1998) Dissemination report on the potential for business angel investments and networks in Europe. EBAN/EURADA, Torquay. EBAN (EUROPEAN BUSINESS ANGEL NETWORK) (2005a) European directory of business angel networks in Europe. EBAN, Brussels.

EBAN (EUROPEAN BUSINESS ANGEL NETWORK) (2005b) Statistics Compendium. EBAN, Brussels.

EUROPEAN COMMISSION (2001) State aid and risk capital, Official Journal of the European Communities C 235, 3-11.

EUROPEAN COMMISSION (2002) Benchmarking of Business Incubators. EC, Brussels. EUROPEAN COMMISSION (2003a) Benchmarking business angels. EC, Brussels. EUROPEAN COMMISSION (2003b) Access to finance of small and medium-sized enterprises. EC, Brussels.

EUROPEAN COMMISSION (2006) The PAXIS Manual for innovation policy makers and practitioners. EC, Brussels. 
EVCA (EUROPEAN VENTURE CAPITAL ASSOCIATION) (2002) Survey of the economic and social impact of venture capital in Europe. EVCA, Zaventem.

FRITSCH M. and FALCK O. (2007) New business formation by industry over space and time: A multidimensional analysis, Regional Studies 41, 157-172.

HARRISON R. and MASON C. (1996a) Informal venture capital: Evaluating the impact of Business Introduction Services, Woodhead-Faulkner Ltd., Hertfordshire.

HARRISON R. and MASON C. (1996b) Developing the informal venture capital market: A review of the Department of Trade and Industry's informal investment demonstration projects, Regional Studies 30, 765-771.

HARRISON R. and MASON C. (1999) Editorial: An overview of informal venture capital research, Venture Capital 1, 95-100.

HEIRMAN A. and CLARYSSE B. (2005) The imprinting effect of initial resources and market strategy on the early growth path of start-ups. Working Paper 2005/310, Ghent University, Gent.

HOLMSTROM B. and TIROLE J. (1997) Financial intermediation, loanable funds, and the real sector, Quarterly Journal of Economics 112, 663-691.

JÄÄSKELÄINEN M., MAULA M. and MURRAY G. (2006) Performance of incentive structures in publicly and privately funded hybrid venture capital funds. Paper presented at the International ProACT Conference 2006, Tampere, Finland.

LEMMON M. and ZENDER J. (2004) Debt capacity and tests of capital structure theories. Working paper, University of Colorado and University of Washington.

LERNER J. (1999) The government as Venture Capitalist: The long-run impact of the SBIR program, The Journal of Business 72, 285-318.

LERNER J. (2002) When bureaucrats meet entrepreneurs: The design of effective 'public venture capital' programmes, The Economic Journal 112, F73-F84. 
LERNER J., MOORE D. and SHEPHERD S. (2005) A study of New Zealand's venture capital market and implications for public policy. LECG, Auckland/Wellington.

LUMME A., MASON C. and SUOMI M. (1998) Informal venture capital: Investors, investments and policy issues in Finland. Kluwer Academic Publishers, Dordrecht.

MARTIN R., SUNLEY P. and TURNER D. (2002) Taking risks in regions: the geographical anatomy of Europe's emerging venture capital market, Journal of Economic Geography 2, 121-150.

MASON C. and HARRISON R. (1995) Closing the regional equity gap: The role of informal venture capital, Small Business Economics 7, 153 - 172.

MASON C. and HARRISON R. (2002) Barriers to investment in the informal venture capital sector, Entrepreneurship and Regional Development 14, 271-287.

MASON C. and HARRISON R. (2003) Closing the regional equity gap? A critique of the Department of Trade and Industry's Regional Venture Capital Funds initiative, Regional Studies 37, 855-868.

MASON C. (2006) Informal sources of venture finance, in PARKER S. (Ed) The life cycle of entrepreneurial ventures, pp. 259-299. Springer, New York.

MAULA M. and MURRAY G. (2003) Finnish Industry Investment Ltd: An International Evaluation (Publications 1/2003). Ministry of Trade and Industry, Helsinki.

MAULA M., MURRAY G. and JÄÄSKELÄINEN M. (2007) Public financing of young innovative companies in Finland (Publications 3/2007). Ministry of Trade and Industry, Helsinki.

MURRAY G. (1998) A policy response to regional disparities in the supply of risk capital to new technology-based firms in the European Union: The European Seed Capital Fund Scheme, Regional Studies 32, 405-419. 
MURRAY G. (2007) Venture capital and government policy, in LANDSTRÖM H. (Ed.) Handbook of Research on Venture Capital, forthcoming. Edward Elgar Publishing.

PAUL S., WHITTAM G. and JOHNSTON J. (2003) The operation of the informal venture capital market in Scotland, Venture Capital 5, 313-335.

PRICEWATERHOUSECOOPERS, THOMSON VENTURE ECONOMICS and NATIONAL VENTURE CAPITAL ASSOCIATION (2006) MoneyTree ${ }^{T M}$ Survey.

PURI M. and ZARUTSKIE R. (2007) On the Lifecycle Dynamics of Venture-Capital- and Non-Venture-Capital-Financed Firms. Working Paper Duke University.

SOHL J. (2005) The angel investor market in 2005. Center for Venture Research, Durham. STROOBANDT F., LIEVENS J. and WAEGE H. (2005) Cultuurparticipatie in het Europa van de 15. Vlaanderen 'Best in Class'?, in LIEVENS J. and WAEGE H. (Eds.) Cultuurparticipatie in breedbeeld, pp. 233-264. Uitgeverij De Boeck, Antwerpen.

SUNLEY P., KLAGGE B., BERNDT C. and MARTIN R. (2005) Venture capital programmes in the UK and Germany: In what sense regional policies?, Regional Studies 39, 255-273.

VAN AUKEN H. (2001) Financing small technology-based companies: The relationship between familiarity with capital and ability to price and negotiate investment, Journal of Small Business Management 39, 240-258.

VAN ROMPUY E. (1999) Steun voor Business Angels Netwerken, Press release Flemish Government 18/5/1999.

VENKATARAMAN S. (2004) Regional transformation through technological entrepreneurship, Journal of Business Venturing 19, 153-167.

WONG P.X., HO Y.P., and AUTIO E. (2005) Entrepreneurship, innovation and economic growth: Evidence from GEM data, Small Business Economics 24, 335-350. 
Table 1: Test of the market failure argument

\begin{tabular}{|c|c|c|c|c|c|c|c|c|c|}
\hline & \multicolumn{3}{|c|}{$\begin{array}{l}\text { BAN-backed compared } \\
\text { to: }\end{array}$} & \multicolumn{3}{|c|}{$\begin{array}{l}\text { (1) Non-BA-backed } \\
\text { companies }\end{array}$} & \multicolumn{3}{|c|}{$\begin{array}{l}\text { (2) BA-backed through } \\
\text { another channel }\end{array}$} \\
\hline & Mean & St.Dev. & $\mathrm{N}$ & Mean & St.Dev. & $\mathrm{N}$ & Mean & St.Dev. & $\mathrm{N}$ \\
\hline \multicolumn{10}{|c|}{ PANEL A: Pre-investment comparisons } \\
\hline Return on assets (ROA) \% & -33.22 & 46.55 & 21 & $1.05 * * *$ & 24.72 & 24 & $-15.26 * *$ & 85.25 & 21 \\
\hline Pre-tax profit & -214.81 & 569.63 & 21 & $-3.83 *$ & 164.78 & 24 & -36.41 & 96.98 & 22 \\
\hline Operational profit & -181.10 & 567.15 & 21 & $8.13 * *$ & 166.92 & 24 & -25.09 & 103.59 & 22 \\
\hline Cash flow & -96.52 & 445.21 & 21 & $35.68 * *$ & 175.69 & 22 & -3.36 & 97.57 & 22 \\
\hline Total debt/total assets (\%) & 0.96 & 0.60 & 21 & 0.82 & 0.34 & 24 & 0.81 & 0.56 & 22 \\
\hline \multicolumn{10}{|c|}{ PANEL B: Analysis of post-investment value creation } \\
\hline ROA - Year 0 & -38.53 & 51.34 & 26 & $11.76^{* * *}$ & 19.87 & 29 & -23.23 & 39.21 & 26 \\
\hline ROA - Year 2 & -38.53 & 72.12 & 28 & $12.34 * * *$ & 19.11 & 32 & -32.71 & 69.85 & 45 \\
\hline ROA - Year 3 & -42.38 & 134.23 & 23 & $11.09 * *$ & 21.73 & 26 & -26.36 & 50.63 & 43 \\
\hline ROA - Year 4 & 6.97 & 95.85 & 14 & 5.44 & 10.31 & 19 & -27.32 & 72.15 & 40 \\
\hline
\end{tabular}

$* \mathrm{p}<0.10 ; * * \mathrm{p}<0.05 ; * * * \mathrm{p}<0.01$

(1) For the comparisons between BAN-backed and non-BA-backed companies, we used Wilcoxon rank tests

(2) For the comparisons between BAN-backed and the other BA-backed companies, we used MannWhitney tests

Table 2: Evaluation of the contribution to economic development

\begin{tabular}{|l|r|r|r|c|c|r|r|r|r|r|r|}
\hline $\begin{array}{l}\text { Variable } \\
\text { (in 000 EUR) }\end{array}$ & \multicolumn{3}{|c|}{$\begin{array}{c}\text { BAN-backed } \\
\text { compared to: }\end{array}$} & \multicolumn{2}{c|}{$\begin{array}{c}\text { (1) Non-BA-backed } \\
\text { companies }\end{array}$} & \multicolumn{2}{c|}{$\begin{array}{c}\text { (2) BA-backed through } \\
\text { another channel }\end{array}$} \\
\hline & Mean & St.Dev. & N & Mean & St.Dev. & N & Mean & St.Dev. & N \\
\hline Taxes & 3.82 & 7.51 & 11 & $22.09^{* *}$ & 65.51 & 22 & 20.00 & 31.89 & 12 \\
\hline Year 0 & 0.63 & 5.80 & 8 & $21.28^{* *}$ & 41.46 & 25 & 12.42 & 24.14 & 19 \\
\hline Year 2 & 9.67 & 25.24 & 12 & 17.36 & 24.03 & 25 & $28.83^{* *}$ & 49.35 & 18 \\
\hline Year 3 & 73.78 & 144.41 & 30 & $-3.55^{* *}$ & 146.54 & 33 & 148.00 & 415.24 & 46 \\
\hline Average yearly growth \\
\hline Value-added & 0.52 & 1.57 & 21 & $-0.18^{* *}$ & 1.82 & 16 & 2.74 & 8.60 & 44 \\
\hline Employees (FTE) &
\end{tabular}

$* \mathrm{p}<0.10 ; * * \mathrm{p}<0.05 ; * * * \mathrm{p}<0.01$

(1) For the comparisons between BAN-backed and non-BA-backed companies, we used Wilcoxon rank tests

(2) For the comparisons between BAN-backed and the other BA-backed companies, we used MannWhitney tests 